\title{
Separation and the Function of Corporation Law
}

\author{
Ronald J. Gilson ${ }^{\dagger}$
}

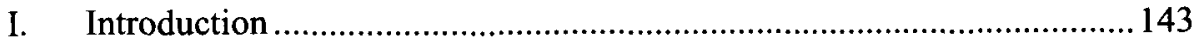

II. Separation and the Pruning of the Criteria of Good Corporation Law.... 144

III. Separation and the Law of Public Corporations ..................................... 146

IV. Separation and the Law of Private Corporations.....................................149

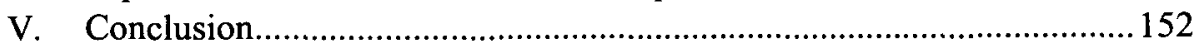

Charles J. Meyers Professor of Law and Business, Stanford Law School, and Marc \& Eva Stern Professor of Law and Business, Columbia Law School. I am grateful to Victor Goldberg, Michael Klausner, and participants at the Mercatus Center conference on Criteria for Good Laws of Business Associations, for comments on an earlier draft. 


\title{
Separation and the Function of Corporation Law
}

\author{
Ronald J. Gilson
}

\section{INTRODUCTION}

I am delighted to participate in taking up Professor William Klein's suggestion that we could learn something by attempting a functional typology of corporation law. As a starting point, any typology must be animated by an underlying theory whose terms dictate the lines the typology draws. I want to focus my contribution at the level of the theory that might animate the architecture of this grid. To see what I mean by this, think of the Sesame Street version of Edward Levi's classic, An Introduction to Legal Reasoning. ${ }^{1}$ The character points at a board on which there are pictures of a number of objects and sings: "One of these things is not like the other; one of these things just doesn't belong." 2 The idea is to teach the children (and law students) to distinguish between categories based on a principle. My concern here is with the principle that might allow us to choose among Bill Klein's litany of potential criteria of good corporate law.

In particular, I will focus on the separation theorem, which states the implications of complete capital markets on shareholder preferences concerning corporate investment policy. My proposition is that the presence of markets in the list of characteristics that determine equity value makes a radical difference in the function played by corporate law. In these circumstances the criteria for good corporate law are limited to a single overriding goal: facilitating the maximization of shareholder wealth. I will illustrate the usefulness of a unicriterion view of corporate law by briefly taking up two familiar issues that span the corporate law domain: the idea of a stakeholder-oriented board of directors in public corporations and the role of the courts in enforcing the reasonable expectations of private corporation shareholders.

This emphasis on the link between markets, asset pricing, and legal institutions has been a familiar theme in my work. For example, I have argued

1. EDWARD LEVI, AN INTRODUCTION TO LEGAL REASONING (1962).

2. The full lyrics are:

One of these things is not like the others,

One of these things just doesn't belong,

Can you tell which thing is not like the others

By the time I finish my song?

Did you guess which thing was not like the others?

Did you guess which thing just doesn't belong?

If you guessed this one is not like the others,

Then you're absolutely ... right!,

available at http://www.rlyrics.com/S\%5CSesameStreet/OneOfTheseThingsIsNotLikeTheOthers.asp. 
that business lawyers function to make up for market failures in asset pricing. Similarly, Reinier Kraakman and I have stressed that familiar institutions operate to alleviate failures in the information market and thereby operate to support price efficiency. ${ }^{4}$ am convinced that the benefit of working out this interaction between the structure of institutions, including here the structure of corporation law, ${ }^{5}$ and the efficiency and completeness of related markets, results in a good deal more than what my friend Bob Mnookin refers to as "cute" theory - that is, theory which appears elegant at first glance, but whose simplicity results not from deep insight but from surface facility.

Of course, the account I offer for this occasion is too brief to convince anyone that I am right. My ambition is only to persuade readers that the question is interesting and the answer worth further consideration. So limited, an objective opens the effort to a criticism another former colleague addressed some years ago. In presenting a paper at a Stanford Law School workshop, Bob Gordon anticipated the kind of comment that I expect many of us have feared was in the minds of the audience even if no one actually said it. At the outset of his presentation, Gordon said he understood that, when they heard his talk, many people in the room would conclude that they could have come up with the same point if they had thought about the problem for three minutes; Gordon acknowledged that the room was full of people who were clever enough to do just what they claimed. He defended his effort, and so will I defend mine, with the simple point that thinking is hard work and three minutes is a long time.

\section{Separation AND the PRUNING OF the CRITERIA OF GOOD CORPORATION} LAW

Now consider the separation theorem. Separation exists when capital

3. Ronald J. Gilson, Value Creation by Business Lawyers: Legal Skills and Asset Pricing, 94 YALE L.J. 239 (1984); Ronald J. Gilson \& Robert Mnookin, Foreword: Business Lawyers and Value Creation for Clients, 74 OR. L. REV. 1 (1995).

4. Ronald J. Gilson \& Reinier Kraakman, The Mechanisms of Market Efficiency, 70 VA. L. REV. 549 (1984); Ronald J. Gilson \& Reinier Kraakman, The Mechanisms of Market Efficiency Twenty Years Later: The Hindsight Bias, 28 J. CORP. L. 718 (2003). Robert Merton has recently generalized this focus on the intersection of institutional structure and imperfect markets in what he styles "a synthesis of function and structure." Robert Merton \& Zvi Bodie, Design of Financial Systems: Toward a Synthesis of Function and Structure (Harvard Business School Working Paper No. 02-074, June 22, 2004), available at $\mathrm{http}: / /$ papers.ssm.com/sol3/papers.cfm?abstract_id=313651.

5. Michael Klausner complains that the term "structure of corporate law" is frequently used but rarely defined. I use the term to reflect the fact that the core of the corporate statute is not a set of rules, but rather the creation of three decision-making bodies-managers, directors, and shareholders-and the assignment of general spheres of authority to each. Corporate decisions then are shaped by the interaction among those components, as influenced by the markets in which the corporation participates. Almost everything non-trivial about corporate law involves the play among those decision makers. See Ronald J. Gilson, A Structural Approach to Corporations: The Case Against Defensive Tactics in Tender Offers, 33 STAN. L. REV. 819 (1981). As Melvin Eisenberg noted almost thirty years ago, in this respect corporate law is constitutional. MELVIN A. EISENBERG, THE STRUCTURE OF CORPORATION LAW 1 (1976). 
markets are sufficiently complete that shareholders can fully diversify, and as a result, shareholder wealth is therefore affected by corporate decisions only through their impact on stock price. In that circumstance, shareholders will be unanimous about the corporation's objective function. Every shareholder is best served if the corporation acts to increase the value of the corporation's stock without regard to risk. In turn, this unanimity makes the function of public corporation law straightforward: legal rules should function to facilitate share value maximization.

This application of the separation theorem has a quick and rather dramatic effect on the list of criteria that Bill Klein would have us assess as potential measures of good corporate law: most of the list disappears. In effect, the separation theorem defines away all of the other goals that Bill Klein treats as part of corporate law, such as fairness, redistribution, control of political and economic power, issues of antitrust, and the like. This pruning of candidates is more than sleight of hand. Rather, the narrow focus reflects a distinction between rules that allow corporations to engage in activities that effectuate their shareholders' unanimity by maximizing share value and rules that seek to regulate those activities for other social purposes. This latter category is part of corporate law only because of a regulator's belief that corporate law is a useful instrument, compared to other alternatives, to accomplish a non-corporate law regulatory objective. Thus, arguments that a particular corporate law rule fosters greater environmental or antitrust compliance are better situated to those domains. I am concerned here with the former category-corporate law as a means to increase shareholder value-because I believe it to be the only distinctive feature of corporate law. ${ }^{6}$

This distinction between the internal function of corporate law and the use of corporate law as a lever to accomplish an external goal parallels the more familiar debate about the use of tax expenditures-that is, provisions of the tax law that harness the tax structure to achieve a different social goal, like providing incentives for favored activities through the provision of tax credits. There has been a lively tax law debate about the circumstances in which tax expenditures are appropriate compared to direct subsidies to the activity in question, and it is well beyond the scope of my effort here to assess the circumstances in which the instrumental use of corporate law is desirable. ${ }^{7} \mathrm{My}$ point is merely that the measure of good corporate law when separation applies is a very focused inquiry: how well does corporate law facilitate maximizing shareholder wealth? All other uses of corporate law should be turfed to the

6. See Jesse Choper, John C. Coffee \& Ronald J. Gilson, Cases and Materials on CORPORATIONS 180 (5th ed. 2000); David Engel, An Approach to Corporate Social Responsibility, 32 STAN, L. REV. 1 (1979).

7. Mark Kelman provides a very helpful account of the tax debate. MARK KELMAN, STRATEGY OR PRINCIPLE? THE CHOICE BETWEEN REGULATION AND TAXATION (1999). 
policy area that motivates the incursion.

\section{SeParation AND THE LAW OF Public CORPORATIONS}

With the criterion for good corporate law when separation applies now in mind, we can address the implication of separation in both of the two broad domains of corporate law: public and private corporations. I take up the implications of the separation theorem for public corporation law in this Part and for private corporations in the next Part. ${ }^{8}$

Because the markets in which the corporation participates-capital, employment, and product-are not perfect, they do not fully solve the corporation's core agency problem. Organizational structure, like capital structure, therefore affects shareholder value. Reflecting Harold Demsetz's insight, corporations in different industries and with different business strategies adopt different structures. ${ }^{9}$ Public corporation law, to facilitate maximizing firm value, should facilitate the process by which companies adopt the most effective organizational form for their business. This includes especially the "market in organizational form," by which I mean the potential for the imposition of a new organizational form through external pressure. The potential for externally induced change serves to ameliorate the frictions in capital, employment, and product markets that allow agency problems to persist.

So what does this get us in terms of the function of corporate law? I will sketch here a few directions in which one might take the point. The general conclusion is that corporation law should facilitate an external market for organizational form by adopting default rules that keep the corporation open to the market, subject to the shareholders making a different choice in a particular circumstance.

First, a separation-based perspective on the function of public corporation law poses a stark challenge to the claim that a stakeholder-oriented board of directors has anything to do with corporate law, as opposed to corporate management. Put bluntly, the claim is either trivial or is trumped by market processes. The claim for a stakeholder orientation is trivial in the sense that one cannot run a successful business without taking seriously the role of nonshareholders whose contributions are important to the corporation's success. ${ }^{10}$

8. For present purposes, I will not try to define the two domains beyond distinguishing between corporations with and without a liquid trading market in their common equity. In particular, I will not use the term close corporation, which carries with it a good deal of baggage that is unnecessary to my analysis.

9. Harold Demsetz, The Structure of Ownership and Control and the Theory of the Firm, 26 J.L. \& ECON. 375 (1983); Harold Demsetz \& Kenneth Lane, The Structure of Corporate Ownership: Causes and Consequences, 93 J. POL. ECON. 1155 (1985).

10. So, for example, those arguing that hostile takeovers are bad for stakeholders need to be clear about whether the point is that doing something for stakeholders makes shareholders better off-an issue 
If something more is meant, the market for organizational form provides a more focused alternative.

Because the production function differs between industries, we observe different roles for stakeholders-providers of inputs other than equity capitalin different industries. For example, the distribution of stock option grants among employees is vastly different in high technology companies and traditional smokestack companies. It is no surprise that technology companies led the chorus of concerns about the impact of accounting rules on the efficiency of getting equity into the hands of employees (even if their arguments do not explain the link between accounting rules and the decision to award options to employees). Because human capital is the dominant input in these companies, options are used far more pervasively than in traditional industries. ${ }^{11}$ Similarly, hostile takeovers are extremely rare in industries where employees and know-how figure larger in the management equation and are far more difficult to transfer to an acquirer without the cooperation of the target. ${ }^{12}$ The point is that markets encourage a management and governance structure that fits the corporation's business. Corporate law has nothing to add to the process.

It follows that default rules, which isolate the corporation from the market by creating barriers to shareholder influence-for example, impediments to shareholders eliminating poison pills or regulation that operates on an "opt-out" rather than an "opt-in" basis - get in the way of assuring a match between a corporation's governance and its business. Some shareholders nonetheless may adopt restrictive governance structures. Google's and Dreamworks' recent use of a Swedish-style, two-class common stock structure with a ten to one voting difference to go public are recent illustrations of Daines \& Klausner's and Coate' $s^{13}$ broader finding that shareholders at the IPO stage frequently adopt mechanisms that shield the company from the market for corporate control (and therefore from the market for organizational form). But the key is that choice, and its reversal, remains with the shareholders who bear the cost or reap the benefit of the particular match between the corporation's organization and control structure and its business. One implication, for example, is that the

of management-or whether the claim is that takeovers raise a distributional issue between stakeholders and shareholders. I continue to be surprised that the debate has gone on this long without a demand for clarity on this point.

11. Ronald J. Gilson \& David Schizer, Understanding Venture Capital Structure: A Tax Explanation for Convertible Preferred Stock, 116 HARV. L. REV. 874 (2003), discuss the importance of equity incentives to entrepreneurial activity and the intuitional structure that developed to support their provision.

12. The success of the Oracle hostile offer for PeopleSoft may be the exception that proves the rule. Since Oracle's initial position was that it planned to eliminate PeopleSoft software following the transaction, transferring the human capital of PeopleSoft employees was hardly central to the deal.

13. Robert Daines \& Michael Klausner, Do IPOs Maximize Firm Value: An Empirical Study of Antitakeover Protections, 17 J.L. ECON. \& ORG. 83 (2001); John C. Coates, Explaining Variations in Takeover Defenses: Blame the Lawyers, 89 CAL. L. REV. 1301 (2001). 
ambiguity in Delaware law regarding shareholder bylaw initiatives should be resolved to allow shareholders to eliminate a poison pill. ${ }^{14}$

The belief that the stock market systematically applies too high a discount rate to future earnings drives the most familiar argument that corporate law provisions favoring a stakeholder-oriented board are not trivial. The claim is that a myopic stock market leads managers to prefer short-term over higher long-term return strategies. For example, managers ignore long-term commitments to stakeholders that are necessary to efficient production in the long run in an effort to boost short-term earnings. Here, however, legal strategies are trumped by the potential for related markets to respond to failures in the primary market. Merton offers a simple example that illustrates how markets can overcome this kind of a bias. ${ }^{15}$ Suppose individuals suffer from a systematic cognitive bias that causes them to underestimate their life expectancies, and therefore to pay too much for life insurance relative to an actuarially fair price. Competition among life insurers (which assumes no significant entry barriers), who do know the actuarial cost of the insurance, will drive the price down to the actuarial fair level despite the systematic bias of consumers. The impact of the bias is corrected by operation of a market that does not suffer from the bias, even though consumers do. The solution is not without cost-transactions costs are associated with the operation of the corrective market response--but the larger the market, the lower the unit costs.

The same type of analysis applies to the claim that investor bias leads to short-term management in public companies. Assume that stock market investors systematically apply too high a discount rate to expected corporate earnings, and further assume that the optimal planning horizon differs in different industries. ${ }^{16}$ Under these assumptions, the stock market will systematically undervalue companies with longer planning horizons relative to companies with shorter time horizons. As with Merton's insurance example, however, a related market can alleviate the bias. The private equity market operates to ameliorate the failure in the market for public corporation equitycompetition among investors who do not suffer from a short-term bias will drive stock price toward an unbiased level. The dramatic growth of the private equity market and the expansion in the range of industries in which private equity funds now operate are consistent with this intuition: a corporation's most efficient source of capital is driven by the character of its business and competitive responses to market failures. ${ }^{17}$

14. See Ronald J. Gilson, Unocal Fifteen Years Later (and What We Can Do About It), 26 DEL. J. CORP. L. 491 (2001).

15. Merton \& Bodie, supra note 4.

16. The assumption of systematic bias also assumes the absence of corrective trading by arbitrageurs. See Gilson \& Kraakman, The Mechanisms of Market Efficiency Twenty Years Later, supra note 4 .

17. The idea that public and private equity are governance alternatives is at the core of Michael 
Again, the lesson for public corporation law is to get out of the way of corrective market responses. When public investors systematically get it wrong, markets will respond. They will do so imperfectly and with significant transaction costs, but the appropriate performance measure is not a perfect market but the performance of the alternative: the role of the Delaware courts in shaping organizational form in a fashion that is difficult for shareholders to change. The same humility that animates the business judgment rule surely teaches that courts will be no better in choosing the right governance structure for a corporation than in evaluating a corporation's business strategy. Nonetheless, judicial doctrine that blocks shareholders from making corrections in the governance structure casts courts in precisely this role. The combination of the separation theorem and related market responses to primary market failures counsels in favor of public corporation law setting as the default a governance structure that opens the corporation to the markets. Where there are claims of short-termism or the need for effective pre-commitment, markets will do a better job of assessing their validity than will a court. And in the end shareholders always can choose a more restrictive structure, but without the barriers that now confront shareholder efforts to eliminate manageriallyimposed restrictions.

\section{SEPARATION AND the LAW OF PRIVATE CORPORATIONS}

Viewing private corporations through the lens of separation yields quite different implications. Because shareholders in private corporations typically invest their human capital along with their financial capital and because of limited liquidity, they cannot diversify their investment. As a result, we would not expect shareholder unanimity on strategy because corporate decisions will affect the shareholders' wealth other than through the value of the stock (which is difficult to determine in any event). As a result, shareholders will not agree that the corporation should maximize firm value without regard to risk or to the value of the shareholders' other assets. To use a familiar example from the case law, a shareholder's employment relation with the corporation may have a greater impact on her wealth than the corporation's strategic decisions. This opens up a role for corporate law that is not present in public corporations. Individuals may be both opportunistic and biased; unlike in the public

Jensen's famous brief for the role of private equity. See Michael Jensen, The Eclipse of the Public Corporation, HARV. BUS. REV. 61 (1989). To be sure, not all governance failures are likely to evoke a corrective response in an associated market. For example, excessive management compensation is not a likely candidate for an easy market fix. Nonetheless, one should not underestimate the breadth of application. For example, a controlling shareholder bears the cost of a continuing mismatch between corporate structure and value maximization. Empirical evidence suggests that over time controlling shareholders correct the mismatch even where it means giving up disproportionate control. See Ronald J. Gilson, Controlling Shareholders and Corporate Governance: Complicating the Taxonomy (Working Paper, Dec. 2004). 
corporation setting, no market operates to correct the problem.

So what is the role for law? Part of the answer is familiar. Corporate law imposes a default rule: what rules would parties, who did not in fact choose a rule to govern the particular dispute, have selected if they had made the decision rationally and with complete knowledge ${ }^{18}$ This default rule approach extends to a judicial role in assessing the distributive issues, cast in terms of fiduciary duty, that are central to the private law of corporations precisely because separation does not apply. A common formulation of this approach is for the court to apply a judgmental default rule: enforce the parties' "reasonable expectations." $" 19$

The absence of separation makes it easy to understand why we are so easily persuaded that courts should be involved in private corporation distributional disputes. For example, the litany of cognitive biases that have been catalogued by psychologists provides persuasive evidence that some people may make systematically bad decisions for a variety of different reasons, leaving the private corporation contract incomplete and shareholders open to opportunism. I imagine that most of us have had the experience of reading the list of entries in a survey of biases and, at least in private, acknowledging with respect to each entry that "I do that." 20 In the case of distributional issues in private corporations, in contrast to Merton's insurance example and the specter of short-termism in public corporations, no market is available to render these mistakes benign. Consequently, an institutional role appears for courts: as mediator of distributional conflicts when the parties, whether because of cognitive bias or other informational barriers, did not anticipate or systematically misapprehended the problems.

But, and here is the insight that I hope warrants three minutes of thought, the same analysis implies significant limits that typically are not acknowledged by courts that take up the challenge of assessing with hindsight the warring parties' previously unstated reasonable expectations. I will discuss two briefly here, but readers surely will have their own additions to the list. One goes to the imperfect ability of the bias literature to dictate a determinative outcome; the second goes to the real risk of judicial hubris.

The first limit simply reflects the indeterminacy resulting from the wide range of biases for whose existence the empirical literature provides support.

18. This formulation is intentionally broad enough to include the concept of default rules operating to force honest negotiating behavior. The nice thing about the symposium's requirement of brevity is that the difficult details can be ignored.

19. For present purposes I will not take up the interesting doctrinal issues that arise when the reasonable expectations standard must be operationalized. For example, are the parties' reasonable expectations fixed at the time of incorporation, or is the court's role akin to a labor arbitrator whose job is to adjust the terms of the arrangement in light of history and current conditions?

20. For a recent survey of the biases and the empirical evidence of biases in the context of the capital market, see Nicholas Barberis \& Richard Thaler, A Survey of Behavioral Finance, in HANDBOOK OF THE ECONOMICS OF FINANCE (George Constantinides et al. eds., 2003). 
The number of biases, taken together with the general absence of precision about which bias or combination of biases are operative in particular circumstances, leaves a decision maker too much freedom in applying the concept to explain the behavior in a particular case. ${ }^{21}$ Moreover, with respect to any particular bias, the experimental literature does not demonstrate that everyone suffers from it; in all studies, a significant portion of the sample appears to be immune. Thus, in a specific case, it may be difficult for a court to actually observe whether a particular bias was operative, with the result that the parties' reasonable expectations remain opaque.

Sam Issacheroff and his colleagues have usefully considered the implications of the bias literature's indeterminacy for its legal application, ${ }^{22}$ in particular the courts' application of this body of social science. They urge its application only in accord with the principle of "asymmetric paternalism." The idea is to rely on the potential for bias only in framing default rules that can be contracted out of by more sophisticated parties. Where the parties do contract out of a default rule, the choice would be respected despite claims that the decision to contract out was itself the product of a bias. In this setting, the court's intervention affects sophisticated and unsophisticated parties differently: the decisions of parties who make an explicit choice are respected, while courts would review the reasonable expectations of those who do not make such a choice.

The second limit generalizes the first: courts should be hesitant in imposing an after-the-fact construction of what the parties really had in mind, even when engaged in the generally useful task of interpreting an incomplete contract or in the context of selecting a default rule. In assessing a court's role in interpreting contracts entered into between firms, Alan Schwartz and Robert Scott recently argued that courts should both limit themselves to strictly textualist interpretations and be parsimonious in their assignment of default rules - in both cases because default rules in the form of standards, like reasonable expectations, too often lead to bad results. ${ }^{23}$ Private corporate law is contract law in positive terms-identifiable individuals elect to go into business with each other on terms more or less ambiguously specified by agreement or statutory default. ${ }^{24}$ Schwartz and Scott assume away most of the power of the

21. "Start with the familiar complaint that the sheer number of biases that have been identified, together with the absence of precision about which bias, or combination of biases, are operative in particular circumstances, leaves too many degrees of freedom in assigning causation." Gilson \& Kraakman, The Mechanisms of Market Efficiency Twenty Years Later, supra note 4.

22. Colin Camerer et. al., Regulation for Conservatives: Behavioral Economics and the Case of Asymmetric Paternalism, 151 U. PA. L. REV. 1211 (2003).

23. Alan Schwartz \& Robert E. Scott, Contract Theory and the Limits of Contract Law, 113 YALE L.J. 541 (2003).

24. This point raises an interesting issue with respect to the breadth of Bill Klein's ambition for a taxonomy of the functions of corporate law. For this purpose, private corporate law simply may be a subset of contract law rather than a subset of the body of law that also covers public corporations. 
cognitive bias evidence by limiting their normative claim to a category of large, sophisticated firms where biases are least likely to influence behavior. However, their concerns about the limited capacity of courts to improve outcomes survive even in the face of a more robust role for individual biases. One powerful implication concerns whether courts should inquire into the reasonable expectations of sophisticated shareholders in large private corporations. In this setting, the Schwartz and Scott position seems as powerful when applied to judicial efforts to fill in the claimed incompleteness of private corporate law as it does in the case of commercial contracts between sophisticated firms. ${ }^{25}$

We are thus left with a tension between the potential for courts to alleviate the distributional inequities that result from individuals contracting incompletely under the burden of cognitive bias or ignorance and the reality that courts are unlikely to be very good at realizing that potential. Reading the cases with this tension in mind might provide some guidance about where the balance actually comes out.

\section{CONCLUSION}

I have argued that viewing corporate law through the prism of the separation theorem advances Bill Klein's project of a functional typology of corporate law and set out two implications derived from this view. First, I suggested that given unanimity concerning the firm's investment policy, the only distinctive element of public corporation law concerns shareholder value maximization; everything else is either management or an extension of a different regulatory regime. Bill's litany of criteria, at least for public corporations, is reduced to one. Second, I suggested that private corporation law leaves room for more specific application of general contract principles, and I left open the possibility that private corporation law is not corporate law at all, but is more appropriately considered a particular application of contract law. The effort to work through this analysis convinces me that Klein's project has value by providing a discipline that forces scholars to be explicit about premises that are too often hidden. Knowing Bill, that is an outcome that would please him.

Framed this way, separation then serves to distinguish between the conceptual domains of corporate and contract law.

25. See CHOPER, COFFEE \& GILSON, supra note 6, at 816-18. 